\title{
Isolation of a bacterial strain from the gut of the fish, Systomus sarana, identification of the isolated strain, optimized production of its protease, the enzyme purification, and partial structural characterization
}

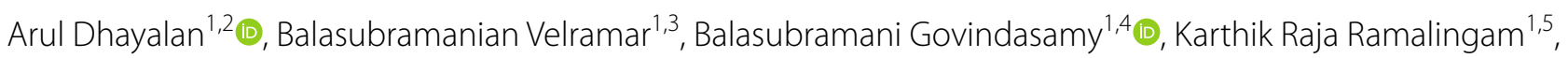
Aiswarya Dilipkumar ${ }^{1,6}$ (D) and Perumal Pachiappan ${ }^{1,7^{*}}$ (D)

\begin{abstract}
Background: The present study focuses on the isolation of Bacillus thuringiensis bacterium from the gut of fresh water fish, Systomus sarana, the innovative optimization of culture parameters to produce maximum protease enzyme, by the isolated bacterium, and the elucidation of peptide profile of the protease. And the experimental data and results were authenticated through the response surface method (RSM) and Box-Behnken design (BBD) model.

Results: During the RSM optimization, the interaction of the highest concentrations (\%) of 2.2 maltose, 2.2 beef extract, and $7.0 \mathrm{pH}$, at $37^{\circ} \mathrm{C}$ incubation, yielded a maximum protease enzyme of $245 \mathrm{U} / \mathrm{ml}$ by the fish gut-isolated, $B$. thuringiensis. The spectral analysis of the obtained enzyme revealed the presence of major functional groups at the range of 610-3852 $\mathrm{cm}^{-1}$ viz., alkynes ( $\mathrm{C} \equiv \mathrm{C}-\mathrm{H}$ : $\mathrm{C}-\mathrm{H}$ stretch), misc (P-H phosphine sharp), a, $\beta$-unsaturated aldehydes, and through PAGE analysis, its molecular weight was determined as $27 \mathrm{kDa}$. The enzyme's MALDI-TOF/MS analysis revealed the presence of 15 peptides from which the R.YHTVCDPR.L peptide has been found to be a major one.

Conclusions: The fish gut-isolated bacterium, B. thuringiensis, SS4 exhibited the potential for high protease production under the innovatively optimized culture conditions, and the obtained result provides scope for applications in food and pharmaceutical industries.
\end{abstract}

Keywords: Bacillus thuringiensis, Enzyme assay, Peptide fingerprinting, Homology modeling, Response surface methodology

\section{Background}

Microorganisms play a vital role in all ecosystems by driving the major biogeochemical cycles, and thus they contribute to almost half of the global primary productivity [1]. In view of the significant role of microbial enzymes in

\footnotetext{
${ }^{*}$ Correspondence: perumalarticles@gmail.com

${ }^{7}$ Department of Marine Science, School of Marine Sciences,

Bharathidasan University, Tiruchirappalli 620024, Tamil Nadu, India

Full list of author information is available at the end of the article
}

biochemical processes, the microbes are considered to be an integral part of biotechnological research. Traditionally produced industrial enzymes are used as biocatalysts with broader applications in various industrial sectors since they are cheaper and eco-friendly, and they can be also used as a substitute for synthetic chemicals during the processing of complex substrates [2]. The gastrointestinal (GI) tract of fish is being colonized by a number of beneficial bacteria called "probiotics." The term probiotic referred to "for life," as opposed to the term antibiotic, 
which means "against life." Fish bodies have a symbiotic relationship with these probiotics. And such microbes help to digest the food, kill the harmful microorganisms, and keep the proper- body functioning of the fishes [3].

Proteases are a group of proteolytic enzymes that catalyze and breakdown the proteins through hydrolysis of peptide bonds between the amino acids of the polypeptide chains. Proteases have been successfully produced by researchers from different microbial sources. Microbes account for a two-thirds share of commercial protease production around the world [4]. Since the advent of enzymology, microbial proteolytic proteases have been the most widely studied enzyme. These enzymes have gained prominence not only due to their vital role in metabolic activities but also due to their immense utilization in industries [5]. The industrial use of such enzymes accounts for nearly $60 \%$ of the total enzyme market [6-8]. Sources of proteases include all forms of life viz., plants, animals, and microorganisms. Based on their acid-base behavior, proteases are classified into three groups: acid, neutral, and alkaline proteases. Acid proteases performed best at the $\mathrm{pH}$ range of 2.0-5.0 and are mostly produced by fungi. Proteases that require around $7 \mathrm{pH}$ are called neutral proteases that are mainly of plant origin, whereas the proteases showing maximum activity at the $\mathrm{pH}$ range of 8 and above are the alkaline ones from microorganisms [9].

Although the protease-enzyme is industrially important, its bulk production involves high costs. Moreover, the presently available microbial culture medium composition shows only moderate influence on enzyme yield, and therefore, formulating a proper fermentation medium is important. The culture medium optimization is a process where components of medium and culture parameters are suitably changed/optimized so as to get better growth/high productivity of the organisms [10]. Therefore, more studies are needed on the optimization of fermentation medium and process conditions to maximize the enzyme production. Some investigations were already carried out in submerged fermentation, in relation to factors like different concentrations of carbon and nitrogen [7].

Several statistical approaches like Box-Behnken design (BBD) and response surface methodology (RSM) have provided scope for the optimization for maximum enzyme production. The Box-Behnken design has been used for the screening of the main factors from a large number of variables, and this information can be retained in further optimization [11]. The present focus is therefore towards the optimization of different components of the medium by innovative statistical methods. Optimization by conventional methods (one factor at a time) is by varying one parameter at a time while fixing other parameters constantly. This method helps to assess the importance of that parameter on the enzyme production [12].

The objective of this work was to isolate the bacterium from the freshwater barb fish gut, molecular identification of the isolated bacterium, and to optimize the growth parameters for enhancing the protease yield of the Bacillus thuringiensis bacterium in potential casein substrate, by adopting innovative statistical tools.

\section{Methods}

\section{Isolation of protease producing bacterium}

Samples of cyprinid fish (Systomus saranus) were collected from the wild, Cauvery River at Stanley Reservoir, Tamil Nadu, India $\left(21^{\circ} 43.232^{\prime} \mathrm{N}, 87^{\circ} 48.884^{\prime} \mathrm{E}\right)$, by using drag net, and the $\mathrm{pH} 7.8-8.4$, water temperature, $27.3-30.1{ }^{\circ} \mathrm{C}$, and salinity $16-18$ ppt were recorded then there. The homogenates of the fish gut tissue were serially diluted up to $10^{-5}$ in sterilized saline, and $100 \mu \mathrm{l}$ from each dilution was spread on tryptic soy agar (TSA, 30 $\mathrm{g} / \mathrm{L}$ ) plates and then incubated aerobically. After enumerating the microbial colonies by plate counting method, pure cultures were raised by using the morphologically different colonies.

\section{Screening of enzyme and enzyme index (EI)}

The protease activity of isolates was screened by a tyrosine hydrolysis test on skim milk agar (SMA) (0.1\% peptone, $0.5 \% \mathrm{NaCl}, 2 \%$ skim milk, and $2 \%$ agar). After streaking of isolates and incubation and $1 \%$ iodine flooding, the appearance of clear zones confirms the activity [13]. The EI was expressed by the relationship between the average diameter $(\mathrm{dm})$ of the degradation halo and the colony growth $(\mathrm{EI}=\mathrm{dm}$ of hydrolysis zone/dm of colony) [14].

\section{Protease enzyme assay}

Each isolate was inoculated in to the medium $(0.1 \%$ peptone, $0.5 \%$ glucose, $0.05 \% \mathrm{NaCl}(\mathrm{w} / \mathrm{v})$, and $0.01 \%$ $\mathrm{MgSO} 4.7 \mathrm{H}_{2} \mathrm{O}$ ) and put in shaking incubator $(150 \mathrm{rpm}$, $48 \mathrm{~h})$. The culture-pellet was centrifuged (10,000 rpm; 150 min at $4{ }^{\circ} \mathrm{C}$ ), then added to it the $500 \mu \mathrm{L}$ of $1 \%$ casein in $50 \mathrm{mM}$ phosphate buffer (pH 7) and $200 \mu \mathrm{l}$ of cell-free supernatant, then incubated in a water bath $\left(40{ }^{\circ} \mathrm{C}, 20\right.$ $\mathrm{min}$ ), and the reaction was terminated with the addition of $1 \mathrm{~mL}$ of $10 \%$ TCA, subsequently kept at room temperature $(15 \mathrm{~min})$. The unreacted casein was separated by centrifuging the mixture, finally the supernatant was added with Na2Co3 (2.5 m ML) and Folin-Ciocalteu phenol and incubated in dark room (30 $\mathrm{min})$. The OD was taken at $660 \mathrm{~nm}$, using the standard [15]. One unit of protease is defined as the amount of enzyme that releases $1 \mu \mathrm{g} / \mathrm{ml} / \mathrm{min}$ of tyrosine. 


\section{“DNA extraction," "PCR amplification," "Agarose gel electrophoresis," and "sequence analysis"}

Bacterial genomic DNA (gDNA) extraction was done according to the method of Sambrook et al. [16] (with slight modification). A volume of $1.5 \mathrm{ml}$ culture broth was centrifuged at $8000 \mathrm{rpm}$ for $10 \mathrm{~min}$. And the collected pellet was suspended in $450 \mu \mathrm{L}$ of TE buffer (vortex mixer). To that pellet, $5 \mu \mathrm{l}$ of lysozyme and $50 \mu \mathrm{l}$ of $10 \%$ sodium dodecyl sulfate (SDS) were added and incubated at room temperature for $1 \mathrm{~h}$. After incubation, an equal volume of phenol:chloroform (1:1) was added, mixed well, and centrifuged at $8000 \mathrm{rpm}$ for $10 \mathrm{~min}$. Then, the aqueous phase was transferred to a fresh tube without disturbing the bottom layer. To the aqueous solution, $50 \mu \mathrm{L}$ of $3 \mathrm{M} \mathrm{NaCH}_{3}$ (sodium acetate) and $300 \mu \mathrm{L}$ of isopropanol were added to precipitate the DNA. Then the mixture was centrifuged at $10,000 \mathrm{rpm}$ for $10 \mathrm{~min}$ and the supernatant was discarded. The collected pellet was washed with $70 \%$ ethanol and centrifuged at 5000 rpm for $1 \mathrm{~min}$. Ethanol was discarded and evaporated without losing DNA. Then the DNA was dissolved with $50 \mu \mathrm{L}$ of TE buffer and the DNA samples were stored at $-20{ }^{\circ} \mathrm{C}$. The partial $16 \mathrm{~S}$ rRNA gene sequence was amplified using universal primers: 27F (5' AGAGTTTGATCMTGGCTCAG 3') and 1525R (5'AAG GAG GTG ATC CAGCCGCA $\left.3^{\prime}\right)$. The reaction mixture $(25 \mu \mathrm{L})$ for PCR amplification was prepared with de-ionized water (7.3 $\mu \mathrm{L}), 10 \mathrm{X}$ Taq buffer $(2.5 \mu \mathrm{L})$, forward primer $(1 \mu \mathrm{M}) 1.0$ $\mu \mathrm{L}$, reverse primer $(1 \mu \mathrm{M}) 1.0 \mu \mathrm{L}$, dNTPs $(10 \mathrm{mM}) 2.0 \mu \mathrm{L}$, Taq polymerase $(3 \mathrm{U} / \mu \mathrm{L}) 0.2 \mu \mathrm{L}$, and DNA template 1.0 $\mu \mathrm{L}$. The program was conducted using 35 cycles of initial denaturation at $94^{\circ} \mathrm{C}$ for $5 \mathrm{~min}$, denaturation at $94{ }^{\circ} \mathrm{C}$ for $60 \mathrm{~s}$, annealing at $55^{\circ} \mathrm{C}$ for $45 \mathrm{~s}$, and elongation at $72{ }^{\circ} \mathrm{C}$ for $1 \mathrm{~min} 30 \mathrm{~s}$ with a final extension at $72{ }^{\circ} \mathrm{C}$ for $7 \mathrm{~min}$ (Verti $^{\text {TM }}$ Thermal Cyclers, Applied Biosystems). The PCR products were analyzed on $1 \%$ agarose gel. Agarose was dissolved completely in the $1 \mathrm{X}$ TBE (Tris-Boric AcidEDTA) buffer and heated in a microwave oven for $5 \mathrm{~min}$. Before solidification at $45^{\circ} \mathrm{C}, 3 \mu \mathrm{L}$ of ethidium bromide $(\mathrm{EtBr})$ was added into the gel solution for visualization of bands. Five microliters of DNA sample was mixed with 2 $\mu \mathrm{L}$ of $2 \mathrm{X}$ loading dye and loaded into the wells. Amplified products were visualized by placing the gel in a UV documentation system (Bio-Rad, Italy). Sequence data was analyzed through the NCBI database (www.ncbi.nlm. nih.gov) by using the BLAST program. The unknown sequence was compared to all of the sequences already available in the database so as to assess the DNA similarities. The obtained nucleotide sequence was deposited in GenBank. Multiple sequence alignment and molecular phylogeny were performed using MEGA7 software [17]. Phylogenetic analysis was performed using the neighborjoining method.

\section{Response surface methodology (RSM)}

A 5-factor Box-Behnken design consisting of 46 investigational runs with 3 replications at the central point (Table 1) was used to optimize the independent variables, i.e., $\mathrm{pH}$, temperature, carbon sources, nitrogen sources, and incubation day. The modeling and numerical analysis were performed using design expert, version 8.0.4.1 software (Stat-Ease Inc. Minneapolis). The quality of fit of the second-order model equation was expressed by the coefficient $R^{2}$, and its statistical significance was determined by an $F$ test. The data were interpreted to obtain the response surface in the form of contours and 3D descriptions by viewing the interaction of the factors.

\section{Effect of culture}

\section{Parameters on protease enzyme production}

The effective strain SS5 was inoculated into the production medium with the following parameters viz., $\mathrm{pH}$ $3-10$, temperatures $10-45^{\circ} \mathrm{C}$, and incubation time $0-60$ $\mathrm{h}$ in rotary shaking at $150 \mathrm{rpm}$. After incubation, the fermented content was centrifuged at $8000 \mathrm{rpm}$ for $10 \mathrm{~min}$ at $4{ }^{\circ} \mathrm{C}$, and the collected supernatants were used for protease enzyme assay in relation to the standard, D-galacturonic acid $(\mu \mathrm{g} / \mathrm{mL})$. The effect of six carbon sources $(1 \%)$ (glucose, sucrose, maltose, galactose, lactose, and mannitol) and six nitrogen sources (1\%) (yeast extract, peptone, $\left(\mathrm{NH}_{4}\right)_{2} \mathrm{SO}_{4}, \mathrm{KNO}_{3}, \mathrm{NaNO}_{3}$, and $\mathrm{KH}_{2} \mathrm{PO}_{4}$ ) on the production of protease were studied. The effective carbon and nitrogen sources were taken as 1 to $4 \%$ for inoculums and incubated at optimum conditions, after which protease assay (enzyme activity) was done [18].

\section{Protein extraction, purification, and molecular mass determination}

After incubation (150 rpm; $48 \mathrm{~h}$ ) of the $1 \times 10^{8}$ microbial inoculum along with nutrient broth, the centrifuged culture material was added with acetone and the precipitated protein was obtained [19]. For gel filtration chromatographic assay, the sample was loaded into the glass column (packed with Sephadex G 100) and proteins were eluted using the Tris-HCL buffer (10mM, pH7.5). After that step, $1.5 \mathrm{ml}$ of fractions was collected separately for the estimation of protein content and protease activity as shown in Table 2 . The protein purification was determined in 12\% SDS-PAGE [20], for which $20 \%$ of protein was loaded on 12\% SDS-PAGE with standard molecule marker (GENEI, Bengaluru, India); then the gel was silver-stained. And the 2-D gel electrophoresis of the lyophilized protein sample was done at Sandor Life Science Pvt. Ltd., Hyderabad. In silico analysis of 2-D gel was performed on the basis of isoelectric point (pI) and molecular weight (MW) of separated proteins. The Expert Protein Analysis System (ExPASy), a SIB 
Table 1 Analysis of variance (ANOVA) for response surface quadratic model (Box-Behnken)

\begin{tabular}{|c|c|c|c|c|c|c|}
\hline Source & Sum of squares & df & Mean square & $F$ value & $\begin{array}{l}p \text { value } \\
\text { Prob }>F\end{array}$ & \\
\hline Model & $93,778.34$ & 20 & 4688.917 & 8.9531 & $<0.0001$ & Significant \\
\hline $\mathrm{A}-\mathrm{pH}$ & 23.5225 & 1 & 23.5225 & 0.0449 & 0.8339 & \\
\hline B-Temperature & 44.65581 & 1 & 44.65581 & 0.0852 & 0.7727 & \\
\hline C- Maltose & 2872.96 & 1 & 2872.96 & 5.4857 & 0.0274 & \\
\hline D- Beef extract & 887.891 & 1 & 887.891 & 1.6953 & 0.2048 & \\
\hline E- Incubation time & 14.5924 & 1 & 14.5924 & 0.0278 & 0.8688 & \\
\hline$A B$ & 4160.25 & 1 & 4160.25 & 7.9437 & 0.0093 & \\
\hline$A C$ & 36.6025 & 1 & 36.6025 & 0.0698 & 0.7937 & \\
\hline$A D$ & 400 & 1 & 400 & 0.7637 & 0.3905 & \\
\hline$A E$ & 2545.203 & 1 & 2545.203 & 4.8599 & 0.0369 & \\
\hline$B C$ & 256 & 1 & 256 & 0.4888 & 0.4909 & \\
\hline $\mathrm{BD}$ & 540.5625 & 1 & 540.5625 & 1.0321 & 0.3194 & \\
\hline $\mathrm{BE}$ & 6.838225 & 1 & 6.838225 & 0.0130 & 0.9099 & \\
\hline$C D$ & 490.6225 & 1 & 490.6225 & 0.9368 & 0.3424 & \\
\hline CE & 2116 & 1 & 2116 & 4.0403 & 0.0553 & \\
\hline $\mathrm{DE}$ & 204.633 & 1 & 204.633 & 0.3907 & 0.5376 & \\
\hline$A^{2}$ & $27,991.69$ & 1 & $27,991.69$ & 53.448 & $<0.0001$ & \\
\hline$B^{2}$ & $24,876.63$ & 1 & $24,876.63$ & 47.500 & $<0.0001$ & \\
\hline$C^{2}$ & $34,419.42$ & 1 & $34,419.42$ & 65.721 & $<0.0001$ & \\
\hline$D^{2}$ & $37,710.85$ & 1 & $37,710.85$ & 72.006 & $<0.0001$ & \\
\hline$E^{2}$ & $38,409.17$ & 1 & $38,409.17$ & 73.339 & $<0.0001$ & \\
\hline Residual & 13092.88 & 25 & 523.715 & & & \\
\hline Lack of fit & $13,092.88$ & 20 & 654.6438 & 1.8657 & & Not significant \\
\hline Pure error & 0 & 5 & 0 & & & \\
\hline Cor total & $106,871.2$ & 45 & & & & \\
\hline
\end{tabular}

SD (22.885); mean (138.948); C.V \% (16.470); PRESS (52371.504); $R^{2}$ (0.907); adjusted $R^{2}$ (0.779); predicate $R^{2}$ (0.510); Adeq precision (10.644)

Table 2 Summary of purification factors of protease by Bacillus thuringiensis (SS5)

\begin{tabular}{|c|c|c|c|c|c|}
\hline Purification steps & Protease activity(U) & $\begin{array}{l}\text { Total protein }(\mathrm{mg} / \\
\mathrm{ml})\end{array}$ & $\begin{array}{l}\text { Specific activity } \\
\text { (U/mg) }\end{array}$ & Purification fold & Yield (\%) \\
\hline Optimized culture crude extract & 483 & 213 & 2.3 & 1.0 & 100 \\
\hline Ammonium sulfate precipitation & 421 & 106 & 3.9 & 1.58 & 87.16 \\
\hline Dialysis & 368 & 43 & 8.8 & 2.21 & 76.19 \\
\hline Sephadex G-100 & 245 & 19 & 12.9 & 2.83 & 50.72 \\
\hline
\end{tabular}

Bioinformatics Resource Portal, provides access to scientific databases and software tools in proteomics, genomics, phylogeny, and systems biology.

\section{High-performance liquid chromatography (HPLC) analysis} The extracellular protease enzyme protein- powder was diluted in $0.2 \mathrm{mM}$ PBS and subjected to HPLC analysis. The samples were detected using an LC-20AD HPLC system (Shimadzu Chromatographic Instruments, Japan) equipped with a $\mathrm{C}_{18}$ reverse-phase column (particle size
$5 \mu \mathrm{m}$ and length $4.6 \times 250 \mathrm{~mm}$ ) and a SPD-20A UV/Vis detector at $272 \mathrm{~nm}$ absorbance with methanol [thin space (1/6-em)]: [thin space $(1 / 6$-em)] water (50[thin space $(1 / 6-\mathrm{em})]$ : [thin space $(1 / 6-\mathrm{em})] 50)$ at a flow rate of $1 \mathrm{ml} /$ min and head pressure of $300 \mathrm{kgf} \mathrm{cm}^{-2}$ [21].

\section{Fourier transform infrared spectroscopy (FT-IR) analysis} The functional groups of protease protein were analyzed using the ART model FT-IR Spectrophotometer. FT-IR spectra of $1 \%$ dry samples were scanned (Nicolet 
spectrophotometer) at the frequency range of 4000-400 $\mathrm{cm}^{-1}$ and at the resolution of $4 \mathrm{~cm}^{-1}$ using $\mathrm{KBr}$ discs [22].

\section{MALDI-TOF/MS analysis}

The manually excised protein spots were digested overnight with trypsin at $37^{\circ} \mathrm{C}$. The $60 \%$ acetonitrile in $0.2 \%$ trifluoroacetic acid was used to extract the peptides from the gels, concentrated by vacuum drying, and desalted by using C18 reverse-phase micro-columns (OMIX Pipette tips, Varian). Micro-column-eluted peptide was added with $3 \mathrm{~mL}$ of matrix solution, and the mixture was subjected to direct analysis in a mass spectrometer sample plate. MALDI-TOF/MS spectrum was obtained by using MALDI-TOF/MS (Axima Performace, KratosShimadzu, and Manchester, UK). The MALDI-TOF/ MS data obtained from each protein digest was analyzed individually by using MASCOT software version 2.2 (Matrix Science, London, UK). Proteins were identified by NCBI database search with peptide $\mathrm{m} / \mathrm{z}$ values using MASCOT search tool (URL http://www.matrixscience. com) for identification of tryptic maps [23].

\section{Homology modeling}

Homology searches were performed with the NCBI BLAST server (http://www.ncbi.nlm.nih.gov/ BLAST/). Homology modeling was performed with SWISSMODEL, a homology-modeling server, by following the protocol of Bordoli et al. [24]. The quality of predicted structural models was assessed through the stereochemical parameters of the Ramachandran plot.

\section{Statistical analysis}

The obtained data were subjected to the statistical treatment of variance test (one-way ANOVA) by SPSS 20.1 software, along with Tukey's tests, and the results at the level of $P<0.05$ were considered to be significant. The data obtained from all the experiments were expressed as mean plus or minus standard error of three replicates.

\section{Results}

\section{Fish- gut bacteria}

Totally, 11 bacterial strains were isolated from the gut of the freshwater fish, Systomus sarana. The viable colonies were spotted from the TSA plates and the mono-populations were observed through a quadrant streak plate (Supplementary Figure S1A). The 11 isolated bacterial strains were named as SS1 to SS11, serially.

\section{Qualitative and quantitative assays}

All the isolated bacterial strains were screened for their nature of enzyme production. The cultured aerobic bacteria in the gut of collected fish revealed the production of protease enzymes. Only SS2, SS3, SS5, SS6, SS7, SS8, and SS10 were able to produce protease enzymes. From the initial screening of enzyme production, most of the bacterial strains have produced translucent zones around the colonies on the skim milk agar medium. Among them, the SS5 strain was found to produce the highest zone of enzyme production. The enzyme index of the SS5 strain revealed the highest zone of clearance as $6.83 \mathrm{~mm}$ (Fig. 1B). For the protease assay, cell-free supernatants of 11 bacterial strains were used for the quantitative assay of protease production. The SS5 bacterial strain exhibited maximum protease activity $(197 \mathrm{U} / \mathrm{mL})$ whereas the SS4 has produced only $85 \mathrm{U} / \mathrm{mL}$ amount of protease (Fig. 1A).

\section{Molecular identification of SS5 strain}

The potential strain-SS5 was found to be a rod-shaped gram-positive bacterium (Supplementary Figure S1A). The PCR amplified fragment was found to comprise of approximately $1300 \mathrm{bp}$ with $1 \mathrm{~Kb}$ DNA ladder
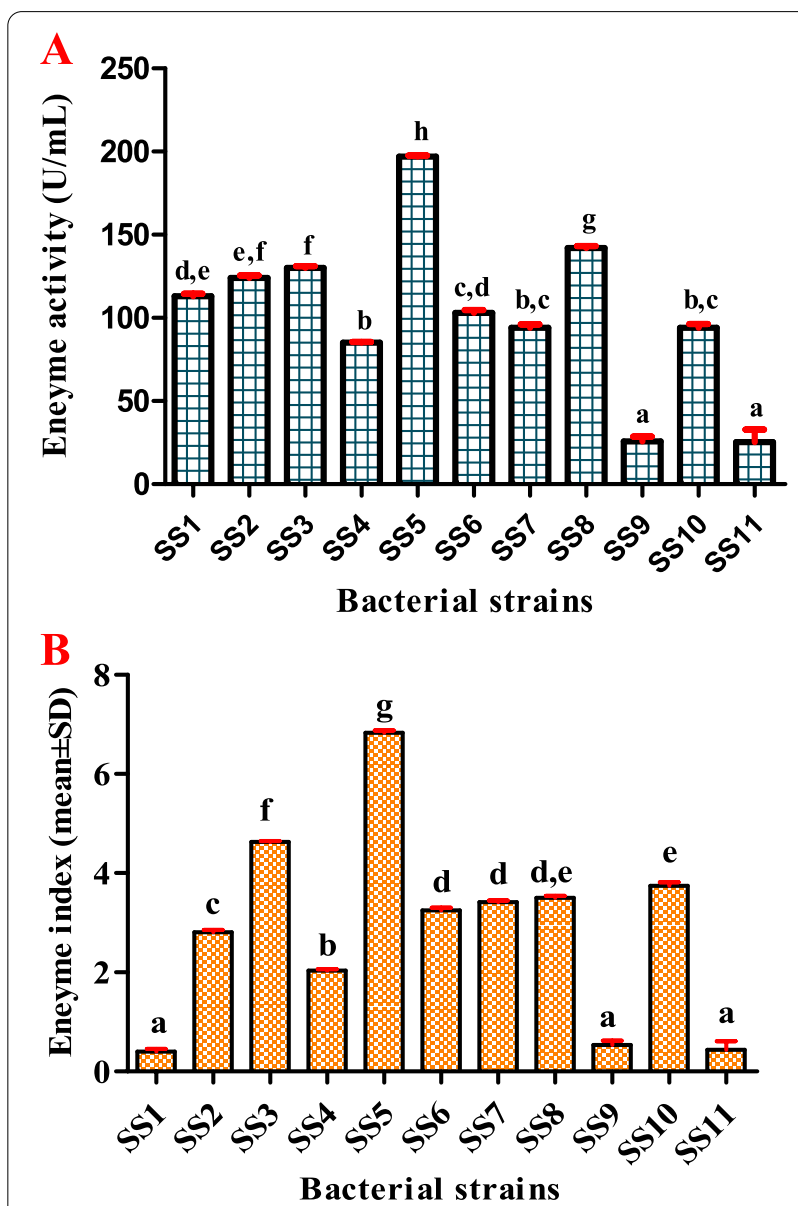

Fig. 1 Quantitative analysis of protease enzymes producing bacterial strains (A); enzyme index (B) 
(Supplementary Figure S1B). From the evolutionary analyses, a total of 1253 bp nucleotides were sequenced for 13 species. Plots of transitions and trans-versions against uncorrected genetic distance indicated an absence of nucleotide saturation in this gene. The optimal tree with the sum of branch length $=0.09432114$ was observed from the constructed tree. The percentage of replicate trees in which the associated taxa clustered together in the bootstrap test (1000 replicates) is shown next to the branches. Based on the analysis, two major clades were obtained in the selected 13 species. One clade consists of a group of 2 species viz., Bacillus oryzaecorticisand Bacillus tequilensis. The species Bacillus thuringiensis was resolved as Bacillus sp. with a high bootstrap value of BP $=56 \%$ (Supplementary Figure S1C).

\section{Optimization of SS5 strain culture conditions}

The culture conditions for protease enzyme production by SS 5 strain were optimized by a total of 46 runs with 5 parameters through the BBD model. Table 1 shows the experimental values of about $95 \%$ significance of predicted values. The test variables were related by the following second-order polynomial equation. Through RSM method of analysis of protease enzyme production in relation to different parameters (under different variables), the enzyme production rate was $245.00 \quad\left(+1.21 * \mathrm{~A}-1.67 * \mathrm{~B}+13.40^{*} \mathrm{C}-7.45^{*} \mathrm{D}-0.96 * \mathrm{E}-\right.$ 32.25*A*B+3.03*A*C+10.00*A*D+25.23*A*E-8.00*B"C+11.62"B*D1.31*B*E+11.07*C*D-23.00*C*E+7.15*D*E-56.63*A2-53.39*B2-62.80*C2-65.73*D2-66.34*E2 ( Table 3 and Fig. 2).

The determination of coefficient $\left(R^{2}=0.907\right)$ was shown by ANOVA of the quadratic regression model, indicating that only $0.65 \%$ of the total variations was not explained by the model. The value of the adjusted determination of coefficient $\left(R^{2}=0.779\right)$ also confirmed that the model was highly significant. At the same time, a very low value of 16.470 of the coefficients of the variation (C.V.) clearly indicated a very high degree of precision and a good deal of reliability of the experimental values (Table 3).

\section{HPLC and FT-IR analytical results}

The HPLC analysis of the extracted protein revealed 12 peaks. Only one was a major peak at the retention time of $9.14(45.63 \%)$ (Table S1). And the left behind nine minor peaks were found at the retention time of 2.60 , $5.78,8.18,9.86,11.62,14.64,18.22,23.84,25.47,27.10$, and 28.45 (Fig. 3A). Totally, 15 functional groups were identified through FT-IR analysis at the respective peaks of $3747,3290,2360,2339,1698,1682,1667,1649,1572$, $1540,1521,1509,1456$, and $1075 \mathrm{~cm}^{-1}$. Based on the available literature and through the standard protocol, the identified functional classes were alkynes $(-\mathrm{C} \equiv \mathrm{C}-\mathrm{H}$ :
$\mathrm{C}-\mathrm{H}$ stretch), miscellaneous ( $\mathrm{Si}-\mathrm{H}$ silane), misc. (P-H phosphine sharp), $\alpha, \beta$-unsaturated aldehydes, ketones $(\mathrm{C}=\mathrm{O}$ stretch$)$, alkenes $(-\mathrm{C}=\mathrm{C}-$ stretch $)$, alkenes $(\mathrm{C}=\mathrm{C}$ stretch), $1^{\circ}$ amines $(\mathrm{N}-\mathrm{H}$ bend), carboxylic acid $(\mathrm{C}-\mathrm{O}$ stretch), amides (NH out of plane), misc. (aromatic, nitro), misc. ( $\mathrm{N}=\mathrm{O}$ nitroso), alkanes $(\mathrm{C}-\mathrm{H}$ bend), and ethers (C-O stretch) (Fig. 3B).

\section{Two-dimensional electrophoretic (2-DE) - results}

The protein molecular weight was found to be $27 \mathrm{kDa}$ as protease enzyme production (Fig. 4B). The 2-DE gel of proteins extracted from the bacterium Bacillus thuringiensis are shown in Supplementary Figure S2. The protein spots on the 2-D gels displayed isoelectric points (pI) at the $\mathrm{pH}$ range of 3-10 and the spots were concentrated between pH 6.5 and pH 7. Two-dimensional electrophoresis was performed on extracellular protease, when it achieved the highest extracellular protease enzyme activity $(245 \mathrm{U} / \mathrm{mL})$.

\section{Protein sequencing and homology modeling results}

Partially purified protease was further subjected to MALDI-TOF analysis (Fig. 5A) and the molecular mass of purified protein was processed for the identification of specific proteins. High qualities of MS/MS spectra were obtained for $25 \mathrm{kDa}$ protein (2383 spectra) (Fig. 5B). The monoisotopic masses of $25 \mathrm{kDa}$ were pooled together and processed with MASCOT (Matrix Science) search; then it was found as protease (Fig. 5C).

Differentially expressed $25 \mathrm{kDa}$ protein was excised, in-gel tryptic digestion was done, and the protein analysis of enzyme sequence was found to consist of 462 residues (Fig. 6A) and also determined 15 peptides namely, -.MSERWTPDSWR.T, R.TKPVLQIPDYPDAK.A, K. A L A D V E A Q L A T F P P LV F A GE A R . N, R.IAGQFAKPRSSPMEK.L, K.LDGVELPSYR.G, R.GDIVNDIAFTAASR.T, R.TPDPQRQLMAYR.Q, R.QLMAYR.Q, K.DSQQSR.R, R.ISDALNFMR.A, R.V D S T T G D W Y A T S G H M I W I G D R . T, R.TRQLDHGHVEYFR.G, R.LIDVLNPDNEPGR.L, K.IGDHLPQMIR.A, and R.YHTVCDPR.L followed as ppm 0.69, - 59.0, - 38.6, - 26.8, - 20.2, - 31.1, 9.46, - 11.3, - 36.4, - 32.8, - 42.0, - 14.1, - 68.2, -23.1 , and 87.1. Homology modeling of the predicted structure was plotted using a Ramachandran plot that revealed the distribution of $\phi$ and $\psi$ angle in the model (Fig. 6B). According to this plot statistics, 90.7\% of residues are located in the most favored region, $8.5 \%$ in the additionally allowed region, and $0.8 \%$ generally allowed region (Table 4), suggesting that its 
Table 3 Composition of various experiments of the PBD for independent variables and response

\begin{tabular}{|c|c|c|c|c|c|c|c|}
\hline \multirow[t]{2}{*}{ Run } & \multirow[t]{2}{*}{$\mathrm{pH}$} & \multirow[t]{2}{*}{ Temperature } & \multirow[t]{2}{*}{ Maltose } & \multirow[t]{2}{*}{ Beef extract } & \multirow[t]{2}{*}{ Incubation time } & \multicolumn{2}{|c|}{ Protease enzyme } \\
\hline & & & & & & $\begin{array}{l}\text { Experimental } \\
\text { value }\end{array}$ & Predicted value \\
\hline 1 & 7.00 & 35.00 & 2.25 & 0.50 & 4.00 & 130 & 128.48 \\
\hline 2 & 10.00 & 35.00 & 0.50 & 2.25 & 32.00 & 101.5 & 110.35 \\
\hline 3 & 7.00 & 35.00 & 2.25 & 2.25 & 32.00 & 244.9 & 244.18 \\
\hline 4 & 4.00 & 35.00 & 2.25 & 2.25 & 4.00 & 135.8 & 146.99 \\
\hline 5 & 7.00 & 35.00 & 4.00 & 0.50 & 32.00 & 106 & 126.24 \\
\hline 6 & 10.00 & 50.00 & 2.25 & 2.25 & 32.00 & 99 & 102.27 \\
\hline 7 & 7.00 & 35.00 & 4.00 & 2.25 & 4.00 & 145 & 153.21 \\
\hline 8 & 7.00 & 50.00 & 2.25 & 2.25 & 4.00 & 138 & 125.86 \\
\hline 9 & 10.00 & 35.00 & 2.25 & 0.50 & 32.00 & 99 & 121.29 \\
\hline 10 & 7.00 & 20.00 & 2.25 & 2.25 & 60.00 & 109.23 & 127.29 \\
\hline 11 & 4.00 & 35.00 & 2.25 & 2.25 & 60.00 & 105.9 & 94.63 \\
\hline 12 & 10.00 & 35.00 & 4.00 & 2.25 & 32.00 & 165.6 & 143.20 \\
\hline 13 & 7.00 & 35.00 & 2.25 & 2.25 & 32.00 & 243.5 & 244.18 \\
\hline 14 & 7.00 & 20.00 & 2.25 & 2.25 & 4.00 & 118 & 126.59 \\
\hline 15 & 4.00 & 20.00 & 2.25 & 2.25 & 32.00 & 84 & 103.18 \\
\hline 16 & 7.00 & 35.00 & 2.25 & 2.25 & 32.00 & 243.5 & 244.18 \\
\hline 17 & 10.00 & 35.00 & 2.25 & 2.25 & 60.00 & 178 & 147.51 \\
\hline 18 & 4.00 & 35.00 & 0.50 & 2.25 & 32.00 & 84 & 113.98 \\
\hline 19 & 4.00 & 35.00 & 2.25 & 4.00 & 32.00 & 137 & 103.97 \\
\hline 20 & 7.00 & 35.00 & 2.25 & 4.00 & 60.00 & 102.5 & 111.67 \\
\hline 21 & 7.00 & 35.00 & 2.25 & 4.00 & 4.00 & 106 & 99.28 \\
\hline 22 & 7.00 & 20.00 & 2.25 & 0.50 & 32.00 & 175 & 146.62 \\
\hline 23 & 7.00 & 50.00 & 2.25 & 4.00 & 32.00 & 106 & 128.38 \\
\hline 24 & 4.00 & 35.00 & 4.00 & 2.25 & 32.00 & 136 & 134.73 \\
\hline 25 & 7.00 & 35.00 & 2.25 & 2.25 & 32.00 & 245 & 244.18 \\
\hline 26 & 10.00 & 20.00 & 2.25 & 2.25 & 32.00 & 167 & 170.11 \\
\hline 27 & 7.00 & 20.00 & 4.00 & 2.25 & 32.00 & 154 & 151.88 \\
\hline 28 & 7.00 & 35.00 & 2.25 & 0.50 & 60.00 & 97.89 & 112.27 \\
\hline 29 & 10.00 & 35.00 & 2.25 & 4.00 & 32.00 & 103 & 126.39 \\
\hline 30 & 7.00 & 35.00 & 4.00 & 4.00 & 32.00 & 110 & 133.49 \\
\hline 31 & 7.00 & 50.00 & 0.50 & 2.25 & 32.00 & 142 & 121.74 \\
\hline 32 & 7.00 & 35.00 & 2.25 & 2.25 & 32.00 & 244 & 244.18 \\
\hline 33 & 7.00 & 20.00 & 2.25 & 4.00 & 32.00 & 136 & 108.47 \\
\hline 34 & 7.00 & 35.00 & 0.50 & 0.50 & 32.00 & 136 & 121.59 \\
\hline 35 & 4.00 & 50.00 & 2.25 & 2.25 & 32.00 & 145 & 164.34 \\
\hline 36 & 7.00 & 35.00 & 0.50 & 4.00 & 32.00 & 95.7 & 84.54 \\
\hline 37 & 7.00 & 20.00 & 0.50 & 2.25 & 32.00 & 100 & 109.08 \\
\hline 38 & 7.00 & 35.00 & 2.25 & 2.25 & 32.00 & 244.2 & 244.18 \\
\hline 39 & 7.00 & 50.00 & 4.00 & 2.25 & 32.00 & 164 & 132.54 \\
\hline 40 & 7.00 & 50.00 & 2.25 & 0.50 & 32.00 & 98.5 & 120.03 \\
\hline 41 & 7.00 & 35.00 & 0.50 & 2.25 & 60.00 & 127 & 124.50 \\
\hline 42 & 10.00 & 35.00 & 2.25 & 2.25 & 4.00 & 107 & 98.97 \\
\hline 43 & 4.00 & 35.00 & 2.25 & 0.50 & 32.00 & 173 & 138.87 \\
\hline 44 & 7.00 & 50.00 & 2.25 & 2.25 & 60.00 & 124 & 121.34 \\
\hline 45 & 7.00 & 35.00 & 4.00 & 2.25 & 60.00 & 100 & 105.30 \\
\hline 46 & 7.00 & 35.00 & 0.50 & 2.25 & 4.00 & 80 & 80.41 \\
\hline
\end{tabular}



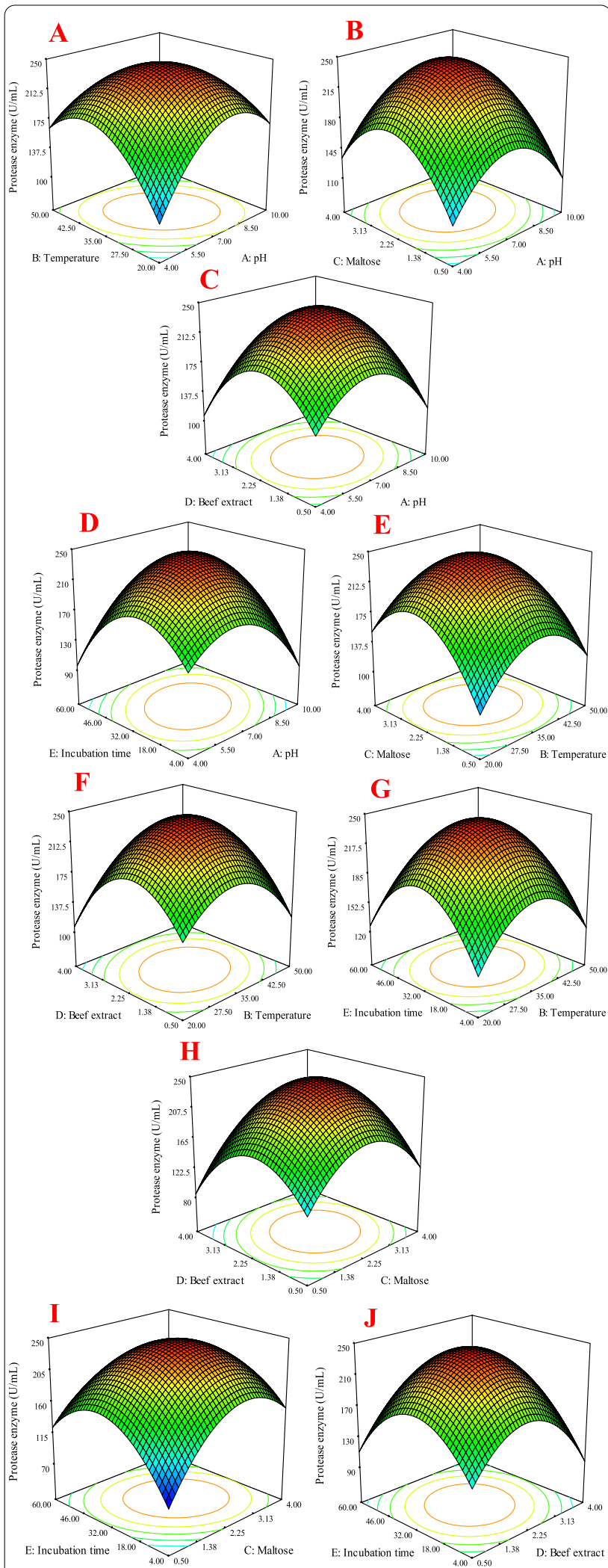

Fig. 2 Five parameter analyses for the protease enzyme production culture condition of Bacillus thuringiensis by RSM three-dimensional structure is likely to be similar to that of protease protein.

\section{Discussion}

Of late, the production of microbial enzymes through the fermentation process has been improved with diverse renewable sources. Generally, for the production of industrial enzymes, the microbial cells are preferred from among the various groups of fungi, bacteria, and yeasts. Earlier, Sun et al. [25] reported that bacteria in fish gut have an important role in the digestion of food as well as in the immunity (of their hosts). Bacterial enzymes help digest the carbohydrates, proteins, and especially the substrate like cellulose which can be digested only by a few animals. According to Ray et al. [26], the extracellular enzyme-producing bacteria in fish gut exert positive effects on the digestive processes of the host. And this is evidenced through the results of the present screening of enzymes from the fish gut bacterium. Protease enzymes from the Bacillus species are the major industrial inputs in various important industrial areas viz., leather processing, detergents, food, waste treatment, and peptide synthesis [27]. Previously, Blanco et al. [27] have reported that the protease enzyme production from Bacillus species has caught increased attention globally because of its important industrial applications in detergents, waste treatment, and in peptide synthesis. Though the proteases are produced by a variety of bacteria like Pseudomonas aeruginosa, Flavobacterium, Clostridium, Achromobacter, and thermo actinomyces besides Streptomyces, only the Bacillus spp. are considered to be a major source as they secrete a variety of soluble extracellular enzymes [28].

The present investigation well established that maximum enzyme production through SS5 could be achieved under the culture medium optimum of; $\mathrm{pH} 7.0$, temperature $36.2 \mathrm{v}{ }^{\circ} \mathrm{C}$, maltose $2.2 \%$, beef extract $2.3 \%$, and incubation time $32 \mathrm{~h}$. Earlier, Padmapriya et al. [29] have reported the highest protease enzyme activity at $\mathrm{pH} 7.0$ by the species of Bacillus genus. Similarly, Govarthanan et al. [30] have optimized the culture conditions for Bacillus sp., and that yielded a maximum $(920 \mathrm{U} / \mathrm{mL})$ protease enzyme at the $\mathrm{pH}$ of 8.0 and temperature of 37 ${ }^{\circ} \mathrm{C}$. The present results are consistent with some previous findings on the protease activity $(821 \mathrm{U} / \mathrm{mL})$ of Bacillus sp. Earlier, Bairagi et al. [31] observed that the optimum proteolytic activity by microbe was found between $\mathrm{pH}$ of 7.6 and 8.4. They have also suggested that physical parameters like $\mathrm{pH}$ and temperature largely influence the production rate and in relation to the type of species. For example, for fungal strains like Fusarium sp., the optimum $\mathrm{pH}$ and temperature have been reported to be 2.5 and $30{ }^{\circ} \mathrm{C}$, respectively and the Bacillus subtilis 

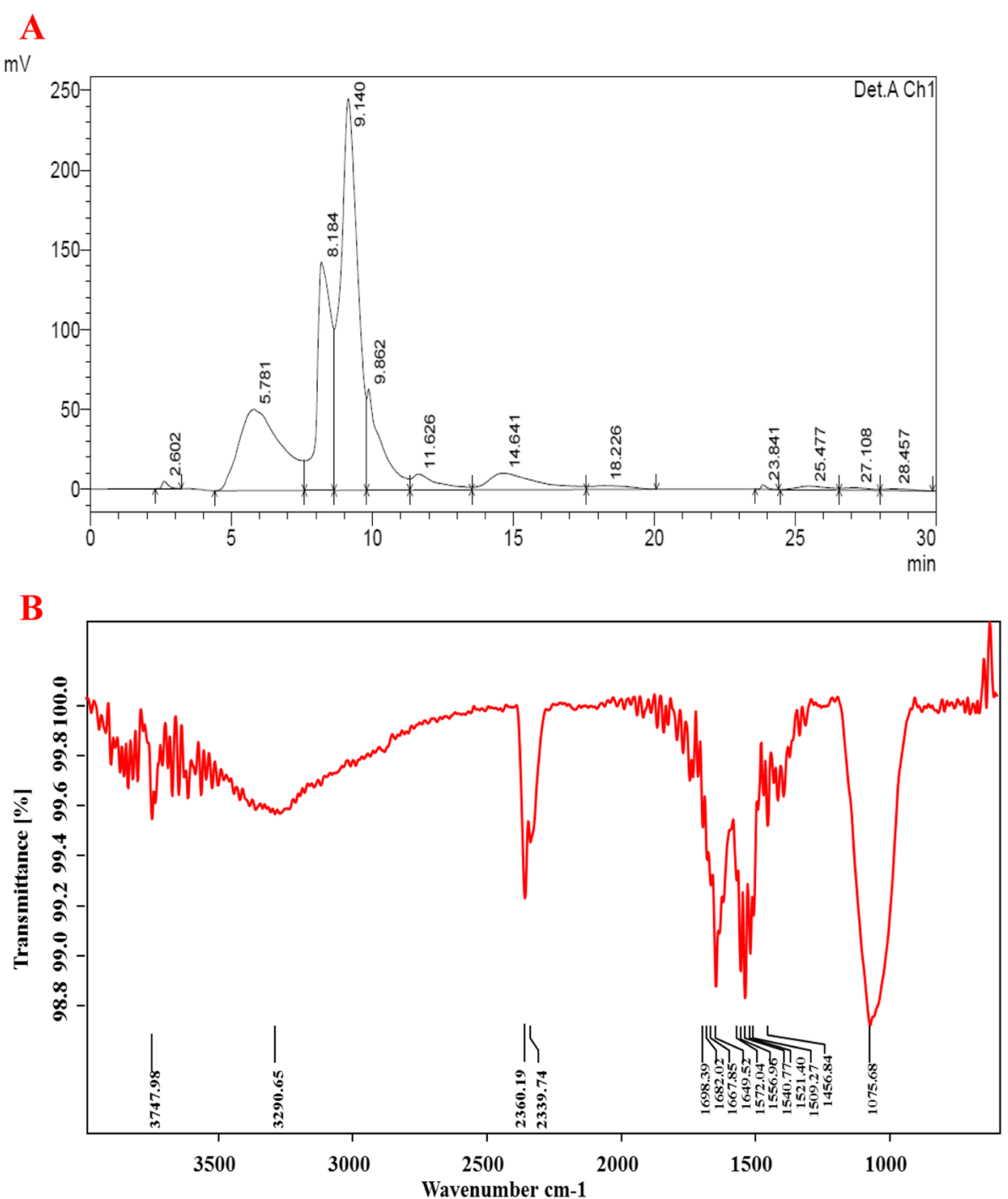

Fig. 3 HPLC analysis of extracted proteins (A); FT-IR analysis of extracted protein for the protease enzyme-producing bacterium of Bacillus thuringiensis (B)

bacterium exhibited good production at $\mathrm{pH} 7.0$ and $35^{\circ} \mathrm{C}$ temperature. Presently, the protease production by the bacterium Bacillus thuringiensis was achieved after $32 \mathrm{~h}$ incubation time, which is almost similar to the report of Asha and Palaniswamy [32], who have reported the incubation period at $48 \mathrm{~h}$ for the maximum protease enzyme production.

RSM is a collection of statistical tools that is useful for designing experiments, building models, evaluating the effects of different factors, and standardizing the optimal conditions of culture factors to get desirable responses [12]. Presently, some scattered spots along the trendline satisfy the assumptions of the BBD model, which also indicates a normal distribution with accuracy and applicability of RSM (Fig. 4A). The RSM plots represent a comparison of the effects of all the factors at the midpoint (coded 0) in the design space (Fig. 2). A curvature with $\mathrm{pH}$, temperature, incubation time, and maltose and beef extract concentration has shown the response to the level of maximum growth. The special features of the RSM tool are 3D response surface curve and point prediction from where we can determine the optimum value of the combination of the five parameters: $\mathrm{pH}(7.0)$, temperature (36.22), incubation time (32), maltose (2.20\%), and beef extract $(2.30 \%)$ that were responsible for the maximum protease enzyme activity $(245 \mathrm{U} / \mathrm{mL})$. The $3 \mathrm{D}$ response surface curve (Fig. 2A-J) determines the optimum condition of each component for maximum 


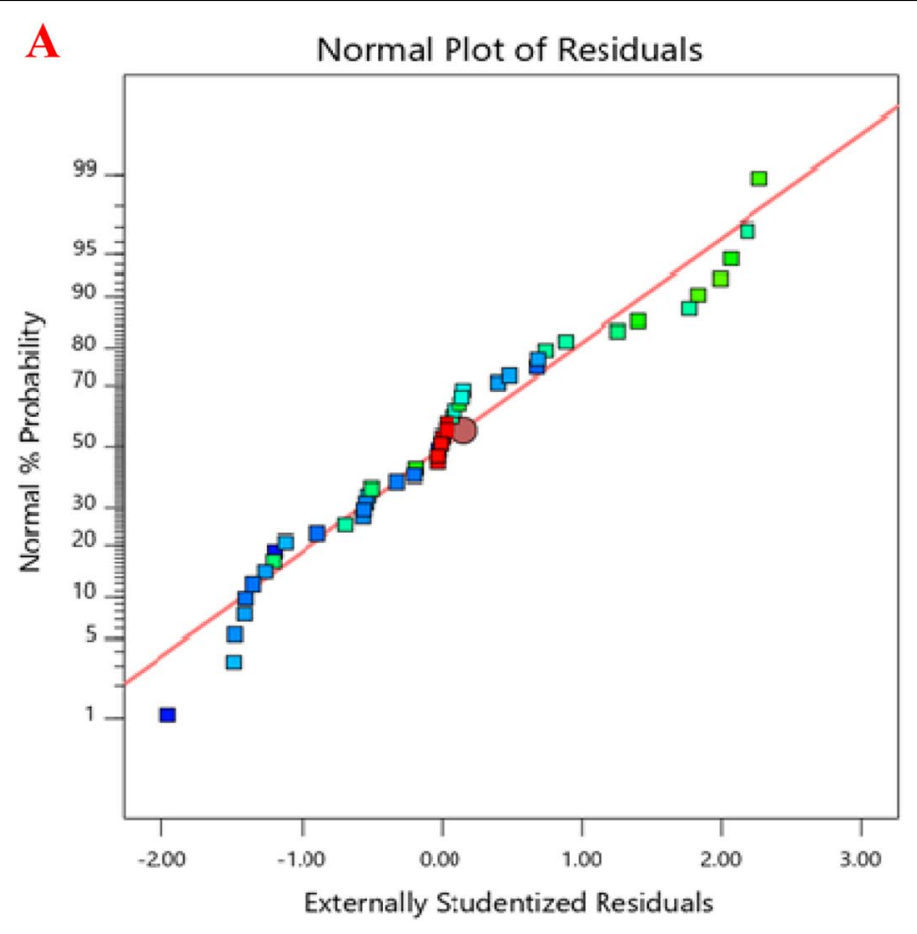

B

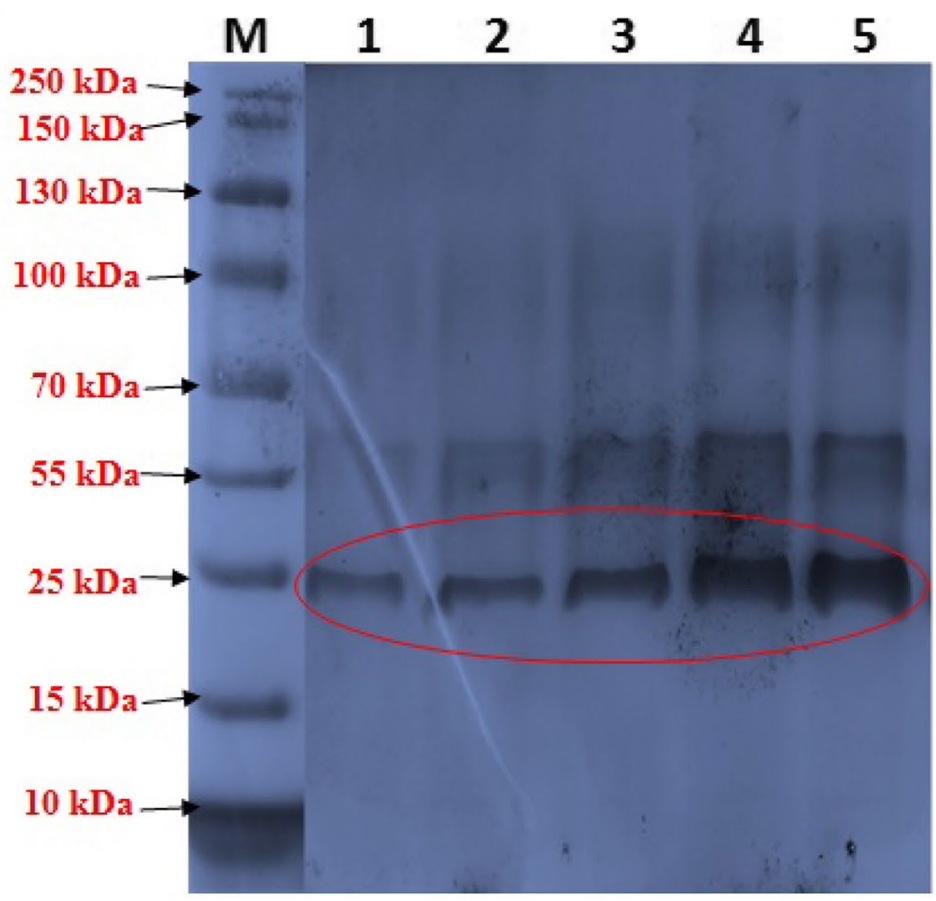

M- Marker; Lane 1- pH (7); Lane 2- Temp (35); Lane 3- Incubation (32h); Lane 4- Maltose (2.2\%) Lane 5-Beef extract (2.3\%)

Fig. 4 Normal probability plot of studentized residual (A); SDS-PAGE analyses by extracellular proteins (B) 

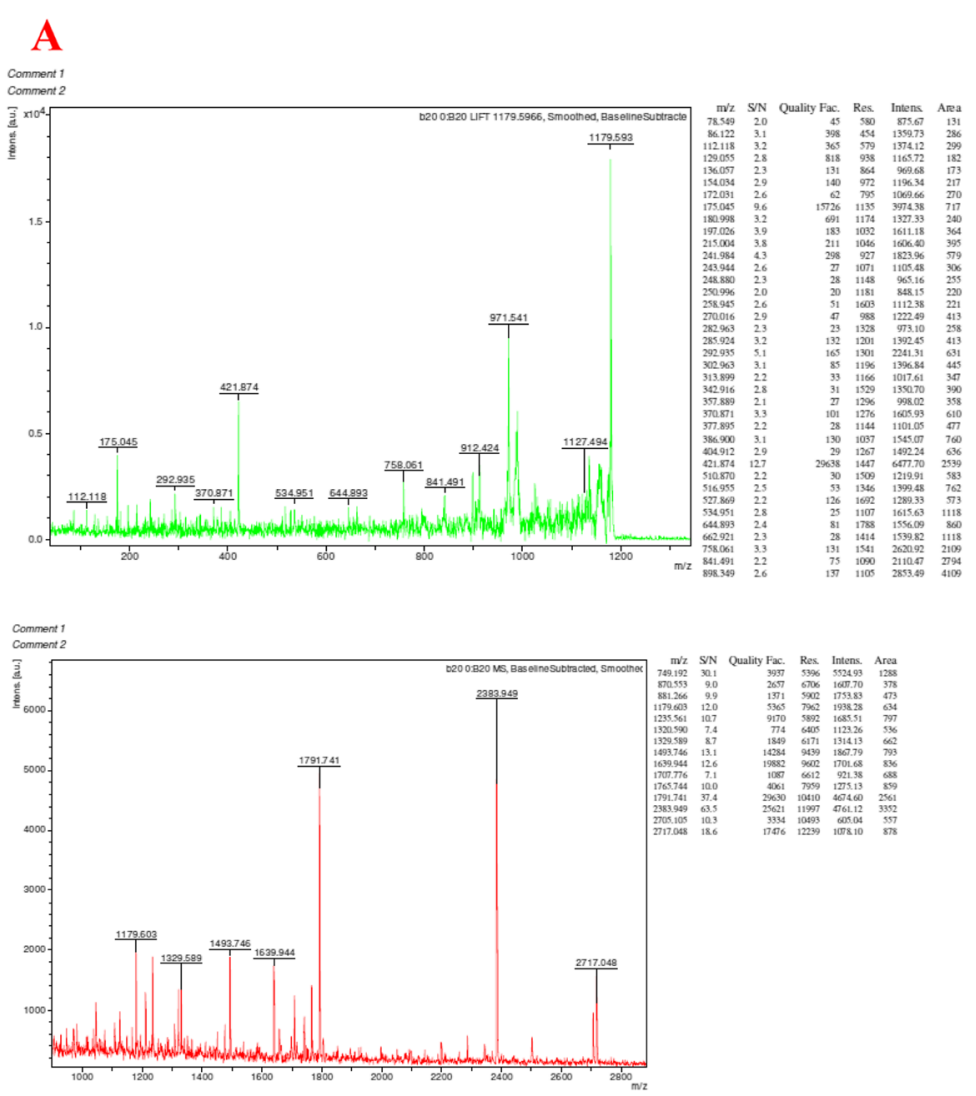

B

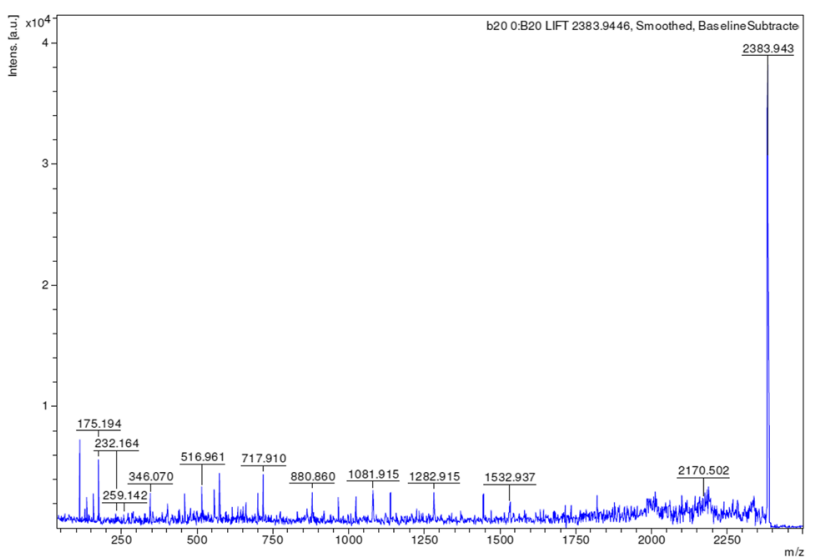

C

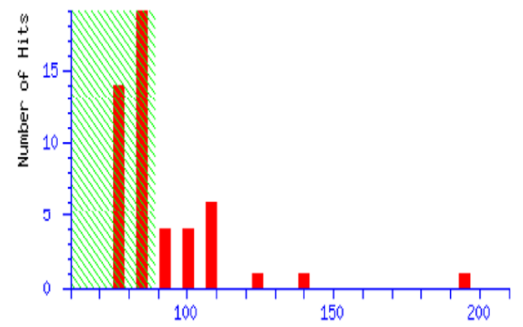

Fig. 5 MALDI-TOF analysis: Intact mass determination (A); protein MS/MS 2383 spectrum (B); Mascot score histogram of the band corresponding to $23 \mathrm{kDa}(\mathbf{C})$ 


\section{A}

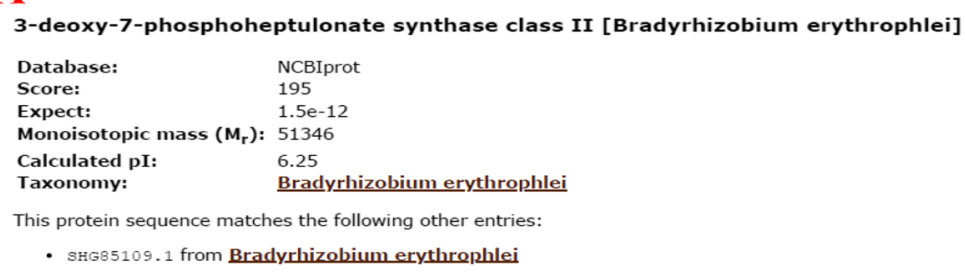

1 MSERWTPDSW RTKPVLOIPD YPDAKALADV EAQLATFPPPL VFAGEARNIR 51 RALARVAAGE AFLLQGGDCA ESFAEHGANN IRDFERVLIQ MAVVLTYAGA 101 IPVVRVGRTA GQFAKPRSSP MERLDGVELP SYRGDIVNDI AFTAASRTPD 151 FQRQLMAYRQ SAATLNIIRA FATGGFANLG SVHQMMLGFI KDSQQSRRYR 201 ELADRISDAL NFMRACGIDL ESHPELRATD IYTSHEALII GYEQAFTRVD 251 STTGDWYATS GHMIWIGDRT RQLDHGHVEY FRGIRNPIGI RCGPSLKTDE 301 LLRLTDVLNP DNEPGRITII NRSGSDRIGD HLPQMTRAVQ REGRVYYNOC

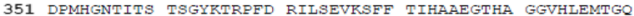
401 DVTECIGGAR AITDEDLNDR YHTVCDPRIN AEQSIDMAFL IAELLKQERA. 451 GRVRFMPVAA GI

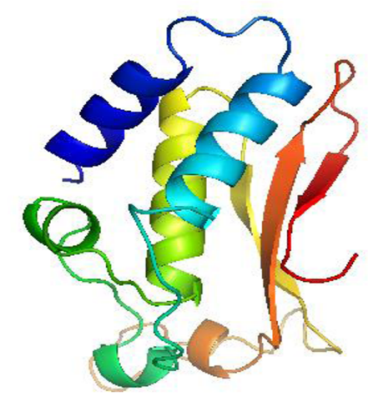

B

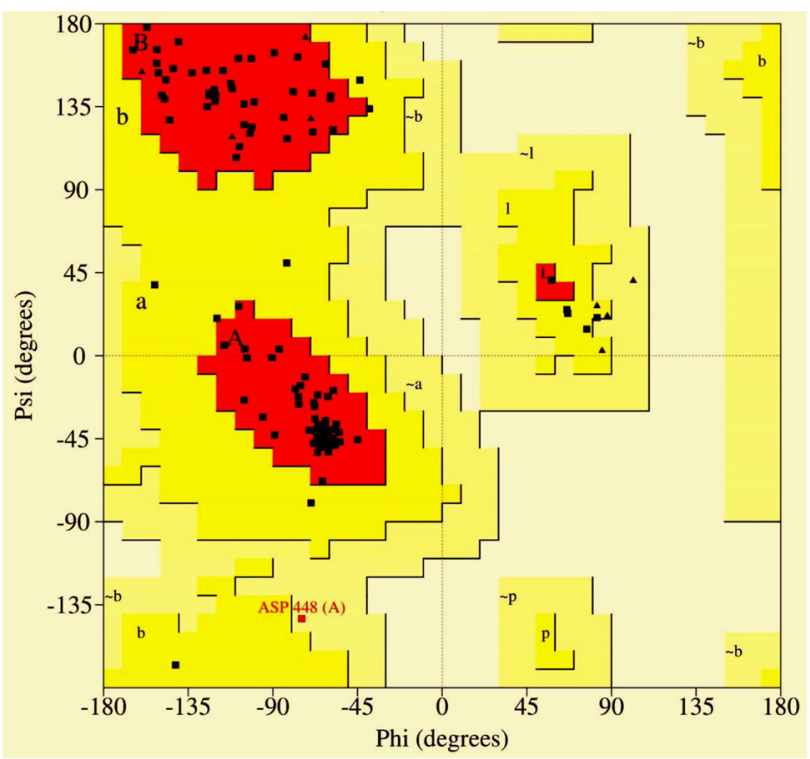

Fig. 6 NCBI database for MS data of purified protease of Bacillus thuringiensis (A); Ramachandran plot of homology-modeled structure (B) 
Table 4 Ramachandran plot analysis of proteins sequences

\begin{tabular}{lll}
\hline Ramachandran plot & $\begin{array}{l}\text { Protease } \\
\text { enzyme }\end{array}$ & Percentage \\
\hline Residues in most favoured regions $[\mathrm{A}, \mathrm{B}, \mathrm{L}]$ & 107 & $90.7 \%$ \\
Residues in additional allowed regions [a,b,l,p] & 10 & $8.5 \%$ \\
$\begin{array}{l}\text { Residues in generously allowed regions } \\
{[\sim a, \sim b, \sim 1, \sim p]}\end{array}$ & 1 & $0.8 \%$ \\
$\begin{array}{l}\text { Residues in disallowed regions } \\
\text { Number of non-glycine and non-proline }\end{array}$ & 0 & $0.0 \%$ \\
residues & 118 & $100.0 \%$ \\
$\begin{array}{l}\text { Number of end-residues (excl. Gly and Pro) } \\
\text { Number of glycine residues (shown as trian- } \\
\text { gles) }\end{array}$ & 2 & \\
$\begin{array}{l}\text { Number of proline residues } \\
\text { Total number of residues }\end{array}$ & 8 & \\
\hline
\end{tabular}

response. These plots were obtained from the pairwise combination of independent factors while keeping another factor at its center point level.

Carbonaro and Nucara [33] have characterized the extracellular protease enzyme through FTIR analysis and obtained the characteristic absorption peaks that ranged between 1600 and $1700 \mathrm{~cm}^{-1}$, and from which they have found that the structure of the enzymatic hydrolysates contained $\mathrm{C}=\mathrm{C}, \mathrm{C}=\mathrm{C}, \mathrm{C}=\mathrm{N}, \mathrm{C}=\mathrm{N},-\mathrm{COOH}$, and $\mathrm{OH}$. In this connection, our present FTIR spectrum of protease revealed quite similar peaks that corresponded to the functional groups of $\alpha, \beta$-unsaturated aldehydes from the Bacillus thuringiensis derived proteins. In an earlier study by Pelton and McLean [34], their IR spectrum revealed the amide II band at $1540-1550 \mathrm{~cm}^{-1}$ and a weaker shoulder at $1510-1525 \mathrm{~cm}^{-1}$. The antiparallel $\beta$-sheet structure of proteins with strong amide II bands between 1510 and $1530 \mathrm{~cm}^{-1}$; a parallel $\beta$-sheet structure was found at somewhat higher frequencies (1530-1550 $\mathrm{cm}^{-1}$ ).

During the present SDS analysis, the molecular weight (MW) of the protease was estimated to be $\sim 25 \mathrm{kDa}$ and $27 \mathrm{kDa}$, and these values closely tally with the previously reported $34 \mathrm{kDa}$ value of serine protease from B. pumilus CBS [35]. Similarly, Uyar et al. [36] have also reported the extracellular protease enzyme value of $27 \mathrm{kDa}$ in $B$. cereus. Likewise, Gessesse et al. [37] have purified a protease of $24 \mathrm{kDa}$ from Bacillus pseudofirmus. Recently, Asker et al. [38] have purified the proteases from Bacillus megaterium that showed a specific activity of $317.23 \mathrm{U} /$ $\mathrm{mg}$ proteins with a purification fold of 7.72, and they have determined its MW as $25 \mathrm{kDa}$.
Presently, the purified protein was quantitatively identified at $2383.943 \mathrm{~m} / \mathrm{z}$ by the mass spectrum, which is considered to be the MW of $27 \mathrm{kDa}$. Recently, Chandrasekaran and Sathiyabama [39] have reported the MW of purified extracellular alkaline proteases as 42 $\mathrm{kDa}$. They have found the sequence IKELATNGVVTNVK (378-391) segment of the alkaline serine protease through the MS/MS spectrum at $1485 \mathrm{~m} / \mathrm{z}$ from the purified fraction. And they have confirmed the purified protein with an exact molecular mass of 43,074.11 Da. Earlier, alkaline proteases have been found to be reported, by researchers, from several fungal strains such as Penicillium chrysogenum FS010 (41 kDa), Penicillium chrysogenum Pg222 (35 kDa), and Aspergillus clavatus ES1 (30 kDa) [40-43]. Similar to some earlier findings, the presently purified protease enzymes showed the protein molecular weight that varied from 24 to $42 \mathrm{kDa}$. During our cost-benefit analysis for the industrial scale production of the protease enzyme, the cost of production of $2 \mathrm{l}$ of enzyme was worked out to be Rs 2000 (approximately). The protease fermentation was scaled up in a 2-L conical flask with a titer of 7572 $\mathrm{U} / \mathrm{mL}$ under optimized fermentation conditions. Further, it is of interest that presently the protein enzyme analysis revealed 462 residues and 15 peptides. During the plot statistics, $90.7 \%$ of residues have been found in the most favored region, $8.5 \%$ in the additionally allowed region, and $0.8 \%$ in generally allowed region (Table 4), revealing the three-dimensional structure of protease protein.

\section{Conclusion}

The present study proved that the $B$. thuringiensis, isolated from the freshwater fish - gut, is an efficient protease producer under the optimized conditions of $7 \mathrm{pH}, 36^{\circ} \mathrm{C}$ temperature, and $2.2 \%$ substrate concentration at $32 \mathrm{~h}$ incubation that could yield $245 \mathrm{U} / \mathrm{mL}$. To the best of our knowledge, this is the first report on the protease enzyme production by the Systomus sarana fish gut-isolated bacterium, $B$. thuringiensis. Based on the presently generated data, further investigation can be made for large-scale enzyme production and its industrial applications.

\footnotetext{
Abbreviations

2-D PAGE: Two Dimensional polyacrylamide gel electrophoresis; FT-IR: Fourier-transform infrared spectroscopy; HPLC: High-performance liquid chromatography; MALDI: Matrix-assisted laser desorption/ionization; MS: Mass spectrophotometry; PCR: Polymerase chain reaction; RSM: Response surface method; SDS-PAGE: Sodium dodecyl sulfate-polyacrylamide gel electrophoresis; SS: Systomus sarana; TSA: Tryptic soy agar.
} 


\section{Supplementary Information}

The online version contains supplementary material available at https://doi. org/10.1186/s43141-022-00299-3.

Additional file 1: Figure S1. Protease enzyme producing bacterium SS5 culture strain, Gram negative bacteria (A); PCR amplified products (B): Phylogenetic tree derived from 16S rRNA sequences after comparing with strain SS5 using neighbor-joining method (C). Figure S2. 2D-Electrophrosesis of protein extract from Bacillus thuringiensis. Table S1. HPLC analysis of protease protein extract from Bacillus thuringiensis SS5.

\section{Acknowledgements}

The authors are grateful to the authorities of Periyar University for providing the necessary facilities to carry out this research work. P.P. is grateful to the UGC, New Delhi, for the grant of the BSR Faculty Fellowship (Ref. No.F.181/2011 (BSR), 26.06.2018).

\section{Authors' contributions}

All authors brainstormed and came up with this study concept. Authors BV and $B G$ provided the chemicals, equipment for the related microbiology tests, and guidelines. Author KR provided Response Surface Methodology (RSM-software) and related guidelines. Author AD provided the glassware and related guidelines. Author PP provided the full manuscript language correction. Author AD provided the bacteria, carried out the experiment, compiled and analyzed resultant data, and compiled this paper with insights from all the other authors. The authors read and approved the final manuscript.

\section{Funding}

This research work was done without funding.

\section{Availability of data and materials}

Materials used and data generated are available.

\section{Declarations}

\section{Ethics approval and consent to participate}

According to the Committee for the Purpose of Control and Supervision of Experiments on Animals-CPCSEA (under Ministry of Environment, Forests and Climate Change, Government of India), the edible fish which are used for laboratory experiments are exempted from obtaining Institutional Animal Ethics Committee (IAEC) approval. The study animal that we have utilized for the present work is Systomus sarana (Hamilton, 1882) which is an edible fish, and hence, the necessity did not arise to acquire the approval from IAEC. However, we have followed the OECD Guidelines for safe handling of experimental animals.

\section{Consent for publication}

As the corresponding author, all authors are agreeing to its publication.

\section{Competing interests}

The authors declare that they have no competing interests.

\begin{abstract}
Author details
${ }^{1}$ Department of Biotechnology, School of Biosciences, Periyar University, Salem 636011, Tamil Nadu, India. ${ }^{2}$ ICAR- National Dairy Research Institute, SRS, Adugodi, Bengaluru 560030, Karnataka, India. ${ }^{3}$ Amity Institute of Biotechnology, Amity University, Raipur 493225, Chhattisgarh, India. ${ }^{4}$ ICAR- Central Institute of Brackishwater Aquaculture, Chennai 600028, Tamil Nadu, India. ${ }^{5}$ Department of Microbiology, Alagappa University, Karaikudi 630003, Tamil Nadu, India. ${ }^{6} 1 / 145$, New Mariyaman Kovil Street, Bominayakanpatti post, Pagalpatti, Salem 636304, Tamil Nadu, India. ${ }^{7}$ Department of Marine Science, School of Marine Sciences, Bharathidasan University, Tiruchirappalli 620024, Tamil Nadu, India.
\end{abstract}

Received: 23 February 2021 Accepted: 7 January 2022

Published online: 10 February 2022

\section{References}

1. Mandic-Mulec I, Stefanic P, Van Elsas JD (2015) Ecology of bacillaceae. Micro Spec 3:3-2. https://doi.org/10.1128/9781555819323.ch3

2. Choi JM, Han SS, Kim HS (2015) Industrial applications of enzyme biocatalysis: current status and future aspects. Biotech Advan 33:1443-1454. https://doi.org/10.1016/j.biotechadv.2015.02.014

3. Sugita H, Okano R, Suzuki Y, Iwai D, Mizukami M, Akiyama N, Matsuura S (2002) Antibacterial abilities of intestinal bacteria from larval and juvenile Japanese flounder against fish pathogens. Fish Sci 68:1004-1011

4. Beg QK, Sahai V, Gupta R (2003) Statistical media optimization and alkaline protease production from Bacillus mojavensis in a bioreactor. Process Biochem 39:203-209. https://doi.org/10.1016/S0032-9592(03)00064-5

5. Younes I, Rinaudo M (2015) Chitin and chitosan preparation from marine sources. Structure, properties and applications. Marine Drugs 13:11331174. https://doi.org/10.3390/md13031133

6. Deng A, Wu J, Zhang Y, Zhang G, Wen T (2010) Purification and characterization of a surfactant-stable high-alkaline protease from bacillus sp. B001. Bioresour Technol 101:7100-7106. https://doi.org/10.1016/j.biortech. 2010.03.130

7. Nisha N, Divakaran J (2014) Optimization of alkaline protease production from Bacillus subtilis NS isolated from sea water. African J Biotech 13:1707-1713. https://doi.org/10.5897/AJB2014.13652

8. Ali N, Ullah N, Qasim M, Rahman H, Khan SN, Sadiq A, Adnan M (2016) Molecular characterization and growth optimization of halo-tolerant protease producing Bacillus subtilis strain BLK-1.5 isolated from salt mines of Karak, Pakistan. Extremophiles 20:395-402. https://doi.org/10.1007/ s00792-016-0830-1

9. Alnahdi HS (2012) Isolation and screening of extracellular proteases produced by new isolated bacillus sp. J Appl Pharma Sci 2:71. https://doi. org/10.7324/JAPS.2012.2915

10. Unni S, Prabhu AA, Pandey R, Hande R, Veeranki VD (2019) Artificial neural network-genetic algorithm (ANN-GA) based medium optimization for the production of human interferon gamma (hIFN- - ) in Kluyveromyces lactis cell factory. Can J Chem Eng 97:843-858. https://doi.org/10.1002/ cjce. 23350

11. Lakshmi BKM, Hemalatha KPJ (2016) Production of alkaline protease from bacillus licheniformis through statistical optimization of growth media by response surface methodology. Ferment Technol 5:130-137. https://doi. org/10.4172/2167-7972.1000130

12. Ahmed SA, Mostafa FA, Helmy WA, Abdel-Naby MA (2017) Improvement of bacterial a-amylase production and application using two steps statistical factorial design. Biocat Agril Biotech 10:224-233. https://doi.org/10. 1016/j.bcab.2017.03.004

13. Silva CR, Delatorre AB, Martins ML (2007) Effect of the culture conditions on the production of an extracellular protease by thermophilic bacillus sp and some properties of the enzymatic activity. Braz J Microbiol 38:253-258. https://doi.org/10.1590/S1517-83822007000200012

14. Hankin L, Zucker M, Sands DC (1971) Improved solid medium for the detection and enumeration of pectolytic bacteria. Appl Microbiol 22:205-209

15. Lowry OH, Rosebrough NJ, Farr AL, Randall RJ (1951) Protein measurement with the Folin phenol reagent. J Biol Chem 193:265-275

16. Sambrook J, Fritsch EF, Maniatis T (1989) Molecular cloning: a laboratory manual. Cold spring harbor laboratory press

17. Kumar S, Stecher G, Tamura K (2016) MEGA7: molecular evolutionary genetics analysis version 7.0 for bigger datasets. Mol Biol Evol 33:18701874. https://doi.org/10.1093/molbev/mst197

18. Pant G, Prakash A, Pavani JV, Bera S, Deviram GV, Kumar A, Panchpuri M, Prasuna RG (2015) Production, optimization and partial purification of protease from Bacillus subtilis. J Tai Univer for Sci 9:50-55. https://doi.org/ 10.1016/j.jtusci.2014.04.010

19. Koontz L (2014) TCA precipitation. Methods Enzymol 541:3-10. https:// doi.org/10.1016/B978-0-12-420119-4.00001-X

20. Laemmli UK (1970) Cleavage of structural proteins during the assembly of the head of bacteriophage T4. Nature 227:680-685

21. Khan MJ, Saraf S, Saraf S (2017) Anti-inflammatory and associated analgesic activities of HPLC standardized alcoholic extract of known ayurvedic plant Schleicheraoleosa. J Ethnopharmacol 197:257-265. https://doi.org/ 10.1016/j.jep.2016.08.021

22. Cakmak G, Togan I, Severcan F (2006) 17ß-estradiol induced compositional, structural and functional changes in rainbow trout liver, revealed 
by FT-IR spectroscopy: a comparative study with nonylphenol. Aquatic Toxic 77:53-63. https://doi.org/10.1016/j.aquatox.2005.10.015

23. Havliš J, Thomas H, Šebela M, Shevchenko A (2003) Fast-response proteomics by accelerated in-gel digestion of proteins. Anal Chem 75:1300-1306. https://doi.org/10.1021/ac026136s

24. Bordoli L, Kiefer F, Arnold K, Benkert P, Battey J, Schwede T (2009) Protein structure homology modeling using SWISS-MODEL workspace. Nat Protoc 4:1-13. https://doi.org/10.1038/nprot.2008.197

25. Sun Y, Yang H, Ling Z, Chang J, Ye J (2009) Gut microbiota of fast and slow growing grouper Epinephelus coioides. Afr J Microbiol Res 3:637-640 https://doi.org/10.5897/AJMR.9000353

26. Ray AK, Ghosh K, Ringø EJAN (2012) Enzyme-producing bacteria isolated from fish gut: a review. Aquac Nutr 18:465-492. https://doi.org/10.1111/j. 1365-2095.2012.00943.x

27. Blanco AS, Durive OP, Pérez SB, Montes ZD, Guerra NP (2016) Simultaneous production of amylases and proteases by Bacillus subtilis in brewery wastes. Braz J Microbiol 47:665-674. https://doi.org/10.1016/J.BJM.2016.04.019

28. Selvam K, Selvankumar T, Rajiniganth R, Srinivasan P, Sudhakar C, Senthilkumar B, Govarthanan M (2016) Enhanced production of amylase from bacillus sp. using groundnut shell and cassava waste as a substrate under process optimization: waste to wealth approach. Biocat Agricul Biotech 7:250-256. https://doi.org/10.1016/j.bcab.2016.06.013

29. Padmapriya B, Rajeswari T, Nandita R, Raj F (2012) Production and purification of alkaline serine protease from marine bacillus species and its application in detergent industry. Europ J Appl Sci 4:21-26

30. Govarthanan M, Park SH, Kim JW, Lee KJ, Cho M, Kamala-Kannan S, Oh BT (2014) Statistical optimization of alkaline protease production from brackish environment bacillus sp. SKK11 by SSF using horse gram husk. Prep Biochem Biotechnol 44:119-131. https://doi.org/10.1080/10826068.2013.792277

31. Bairagi A, Ghosh KS, Sen SK, Ray AK (2002) Enzyme producing bacterial flora isolated from fish digestive tracts. Aquac Int 10:109-121

32. Asha B, Palaniswamy M (2018) Optimization of alkaline protease production by Bacillus cereus FT 1 isolated from soil. J App Pharm Sci 8:119-127. https://doi.org/10.7324/JAPS.2018.8219

33. Carbonaro M, Nucara A (2010) Secondary structure of food proteins by Fourier transforms spectroscopy in the mid-infrared region. Amino Acids 38:679-690. https://doi.org/10.1007/s00726-009-0274-3

34. Pelton JT, McLean LR (2000) Spectroscopic methods for analysis of protein secondary structure. Anal Biochem 277:167-176. https://doi.org/10. 1006/abio.1999.4320

35. Jaouadi B, Ellouz-Chaabouni S, Rhimi M, Bejar S (2008) Biochemical and molecular characterization of a detergent-stable serine alkaline protease from Bacillus pumilus CBS with high catalytic efficiency. Biochimie 9:1291-1305. https://doi.org/10.1016/j.biochi.2008.03.004

36. Uyar F, Porsuk I, Kizil G, Yilmaz El (2011) Optimal conditions for production of extracellular protease from newly isolated Bacillus cereus strain CA15. Eurasian J Biosci 5:1-9. https://doi.org/10.5053/ejobios.2011.5.0.1

37. Gessesse A, Hatti-Kaul R, Gashe BA, Mattiasson BO (2003) Novel alkaline proteases from alkaliphilic bacteria grown on chicken feather. Enzym Microb Technol 32:519-524. https://doi.org/10.1016/S0141-0229(02)00324-1

38. Asker MM, Mahmoud MG, El Shebwy K, Abd el Aziz MS (2013) Purification and characterization of two thermostable protease fractions from bacillus megaterium. J Genet Eng Biotech 11:103-109. https://doi.org/10.1016/j. jgeb.2013.08.001

39. Chandrasekaran M, Sathiyabama M (2014) Production, partial purification and characterization of protease from a phytopathogenic fungi Alternaria solani (E II. And Mart.) Sorauer. J Basic Microbiol 54:763-774. https://doi. org/10.1002/jobm.201200584

40. Wahab WA, Ahmed SA (2018) Response surface methodology for production, characterization and application of solvent, salt and alkalitolerant alkaline protease from isolated fungal strain Aspergillus Niger WA 2017. Inter J Biolog Macromle 115:447-458. https://doi.org/10.1016/j.jibio mac.2018.04.041

41. Zhu HY, Tian Y, Hou YH, Wang TH (2009) Purification and characterization of the cold-active alkaline protease from marine cold-adaptive Penicillium chrysogenum FS010. Mol Biol Rep 36:2169-2174. https://doi.org/10.1007/ s11033-008-9431-0

42. Benito MJ, Rodríguez M, Núnez F, Asensio MA, Bermúdez ME, Córdoba JJ (2002) Purification and characterization of an extracellular protease from Penicillium chrysogenum Pg222 active against meat proteins. Appl Environ Microbiol 68:3532-3536. https://doi.org/10.1128/AEM.68.7.3532-3536.2002
43. Hajji M, Kanoun S, Nasri M, Gharsallah N (2007) Purification and characterization of an alkaline serine-protease produced by a new isolated Aspergillus clavatus ES1. Process Biochem 42:791-797. https://doi.org/10. 1016/j.procbio.2007.01.011

\section{Publisher's Note}

Springer Nature remains neutral with regard to jurisdictional claims in published maps and institutional affiliations.

\section{Submit your manuscript to a SpringerOpen ${ }^{\circ}$ journal and benefit from:}

- Convenient online submission

- Rigorous peer review

- Open access: articles freely available online

- High visibility within the field

- Retaining the copyright to your article

Submit your next manuscript at $\boldsymbol{\nabla}$ springeropen.com 